\title{
RESIDENCY REPORT: BUINHO
}

\author{
Jane Venis and Hannah Joynt
}

\section{BACKGROUND}

In September 2019 we jointly undertook the Buinho Creative Residency' in Messejana, a historic town in southeastern Portugal. We envisaged that our drawing and music collaboration would benefit from the period of intense focus that a residency would offer - in particular, working daily in a shared living and studio space with no other commitments but our art practice. When we applied, our intended focus was to make works of a longer duration than we had in previous collaborations and experiment with new materials and processes. We were also keen to make some work within the community of Messejana, but weren't sure what shape that would take.

We stayed in the house of São Joao, a remodelled nineteenth-century adobe cottage with an open-plan shared studio, one of two residency houses in the village. The Buinho coordinators, Carlos Alcobia and Monica Reiss, have an ongoing vision that the network will grow in the future to encompass more houses. Buinho's focus is twofold. Firstly, they facilitate community arts and design education by delivering free creative workshops in poor rural schools; and secondly, they offer international artists the opportunity to work in peaceful surroundings and engage with each other and the community. This local and international engagement is breathing new life into a village that had become a casualty of urban attrition.

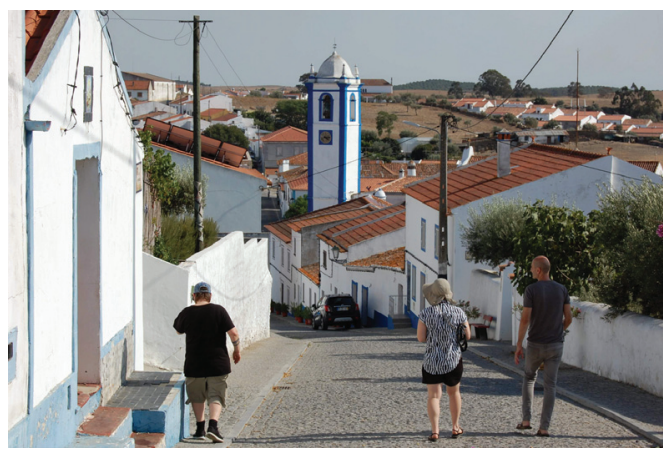

Figure I. Messejana village, southeastern Portugal. Photograph: Maria Lusquiños Torres.

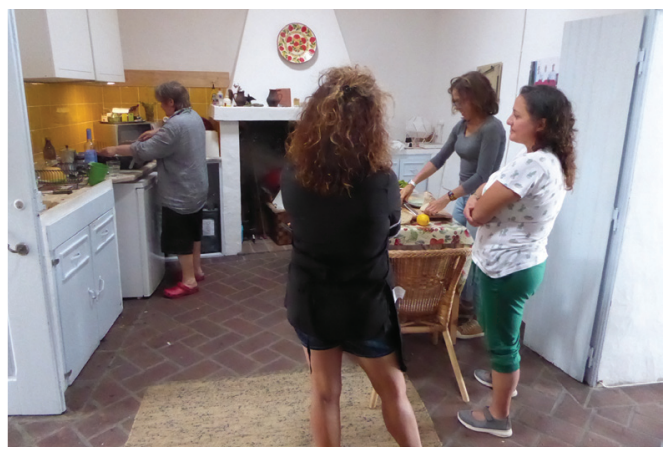

Figure 2. The House of São Joao, Messejana Village. Photograph: Maria Lusquiños Torres.

Before undertaking the Buinho Residency, our collaborative practice focused on exploring the creative languages of both drawing and music within the "performance drawing" genre. ${ }^{2}$ Our practice was process-driven and experimental as we exchanged marks and sounds on the fly, creating live works in gallery and studio settings. We set off for Portugal imagining that we would develop this type of process further. However, when reflecting on the experience of Buinho, we realised that not only had our performance drawing practice changed (as one would expect), but that we had developed a completely new and unforeseen body of work.

In this report we discuss these experiences in the relaxed format of an artist's conversation. 


\section{THE CONVERSATION}

Jane: Messejana it was so magical, wasn't it? And so warm after coming from Dunedin in September. It was around 30 degrees and because the heat was dry, it wasn't like the muggy, oppressive heat in Dubai where we had a stopover.

Hannah: In Messejana the pace of the village was really relaxed; there were no sharp edges and the only job we had to do was be there and make some art.

Jane: My first impression was that the colours of Messejana were so different, as the dust in the atmosphere made everything soft and muted. It reminded me of Central Otago, the browns and the rocky terrain.

Hannah: Yes, a little bit, but not as harsh.

Jane: How do you think the colours affected your painting? How did the colours of the place come through in your work?

Hannah: Firstly, there was no green in the palate, and no blues, other than the sky and the little accents of primary blue that is painted on the outside of houses, around doors and windows. Apart from the sky and the olive trees, the palate of the place is entirely warm. Lots of ochres, umbers, burnt sienna, flesh tones, and a lot of yellow and cream colours and earth tones. There were the eucalyptus trees, but they are similar to an olive-tree green. So the predominantly warm, soft and dry palate is completely opposite to the cold, rich, wet palate we have here because of the predominance of wet greens and dark tones.

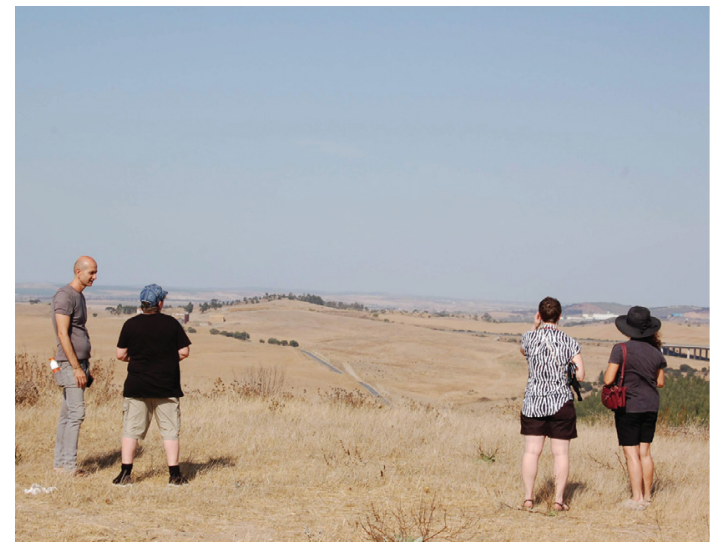

Figure 3. The Messejana Hills.

Photograph: Maria Lusquiños Torres.

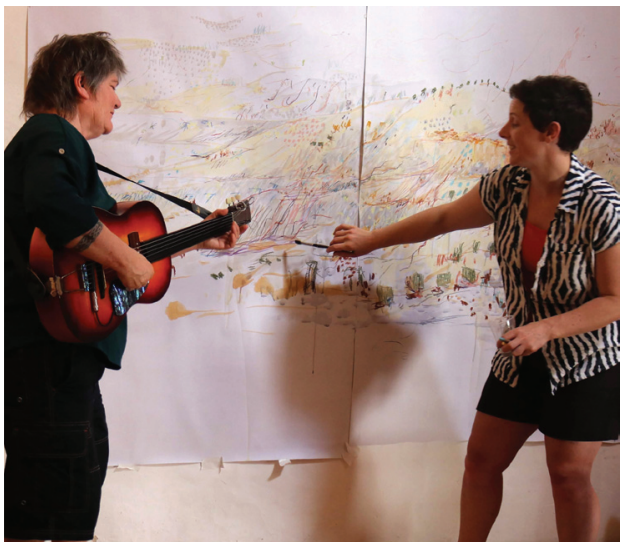

Figure 4. Hannah Joynt and Jane Venis, Messejana Jantar work in progress. gouache and oil pastel on paper. Photograph: Maria Lusquiños Torres.

Jane: Interestingly, the palate of my music was also warm. My music was very relaxed and gentle and I found myself playing the kind of sounds that I tend to play in the summertime in New Zealand, but more slowly meandering - I think that reflected the pace of life in the heat and the muted colours in the landscape.

Hannah: I'm making a connection between the process of warm air and the way that it rises - lightness, a sensation of floating, qualities that have become embedded characteristics of your music. 


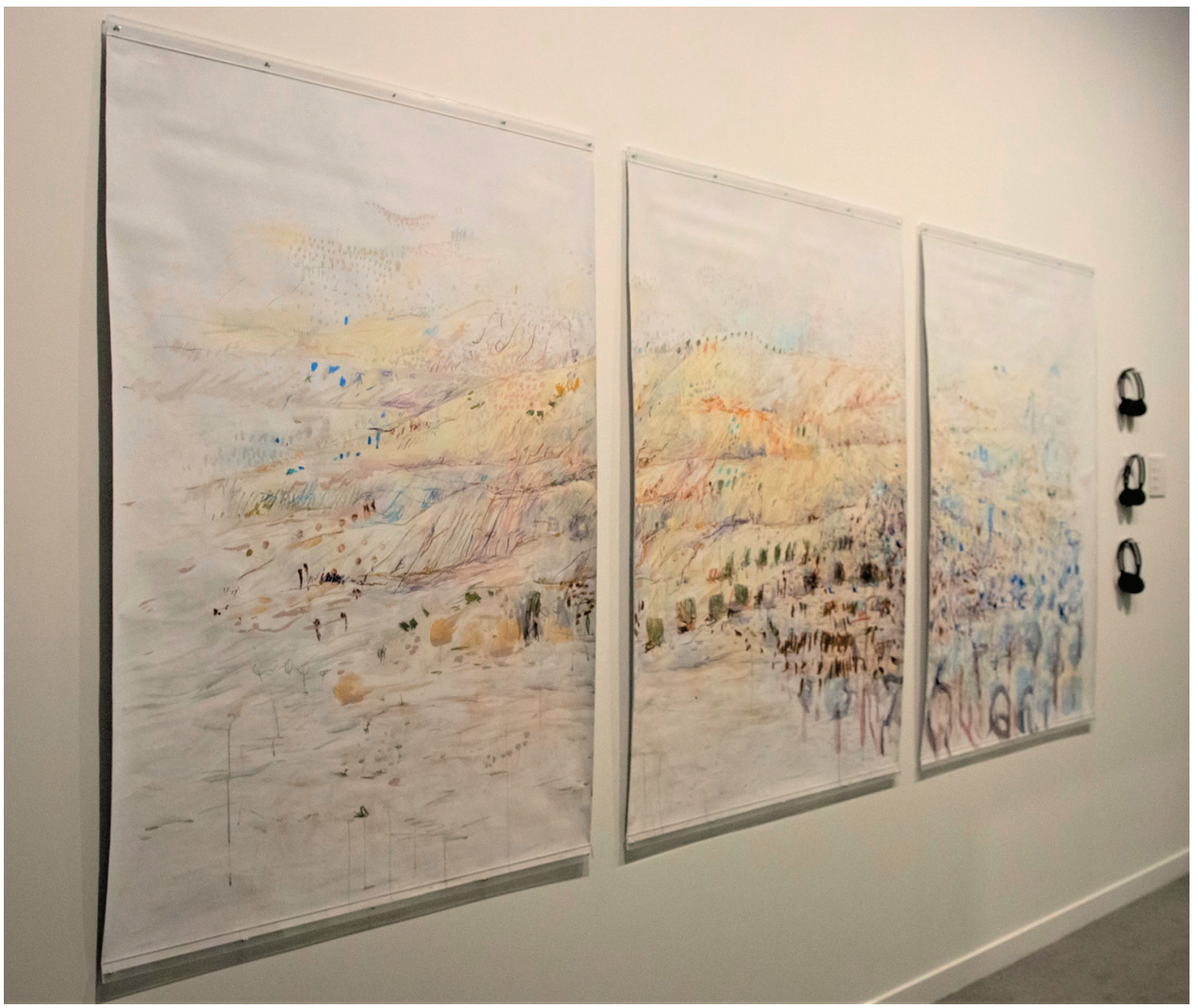

Figure 5. Hannah Joynt and Jane Venis, Three Panel Painting: Messejana Jantar. 2019, gouache and oil pastel on paper. As part of Drawn to Sound Ashburton Gallery 2010 -20.

Photograph: Joe Gallagher.

Link to soundtrack: https://soundcloud.com/dr-clawhammer/jane-venis-messejana-track-3

Jane: Yes, I totally agree; it had a cyclic, meditative quality, especially at first. However, it wasn't always quiet in Messejana - it took a while to get used to the local soundscape. Here we were in a tiny village well away from anywhere, and there was this constant barking of dogs and crowing of roosters, and the hourly clanging of the town bell. It was so hard to sleep at first. On some of my live recordings I hear the dogs - they have become embedded in the work.

Hannah: It was the voice of Messejana ... and the occasional car or traffic noise. That was a big difference in the soundscape. For me, it was the lack of residential traffic noise - there were just not many cars there. But as the houses are built right up to the street side, and the streets are very narrow, the few cars tend to roar around a full speed.

Jane: The architecture was really different - those adobe buildings which are quite ancient are so beautiful and so different from NZ. I remember looking around at the residency website images of the Buinho houses and thinking, "Where are the air conditioning units? It's going to be 35 degrees when we arrive and there are no air conditioners. OMG, we are going to roast!' Yet, these buildings are incredibly cool as the walls are very thick adobe and brick, with small windows, and you step down into an almost basement area and the roof rises up to create a large, cavernous space that is quite cool. It's a different world. 
Hannah: I liked the way that the architectural space was not obvious from the outside of the building. As you enter the building the space reveals itself as you explore it. Remember the museum - there was that big walled-in garden of orange trees out the back; the architectural spaces reveal themselves to you slowly. The scales and spaces of buildings are not obvious, and I like that. You would never know what's behind a building's façade from the street side. We had the lovely courtyard garden at the back of our residency house.

Jane: I think that is all to do with the pace of life, too. You arrive and it's very low key, and things are not obvious from the beginning and things unfold as you go - with no rush, things are discovered bit by bit. For me, it was all part and parcel of the music that I made. My first pieces were made on the fretless guitar. It's a slow instrument - you don't play speedy things on a fretless guitar. As there are no frets you have to you find your way, sliding around bit by bit up the fretboard and discovering things slowly. It was the perfect instrument to start off making music in the village. Yep, Messejana - the slow reveal!

Hannah: Yes, it also made me think of the fact there are no signs for shops, so you don't know

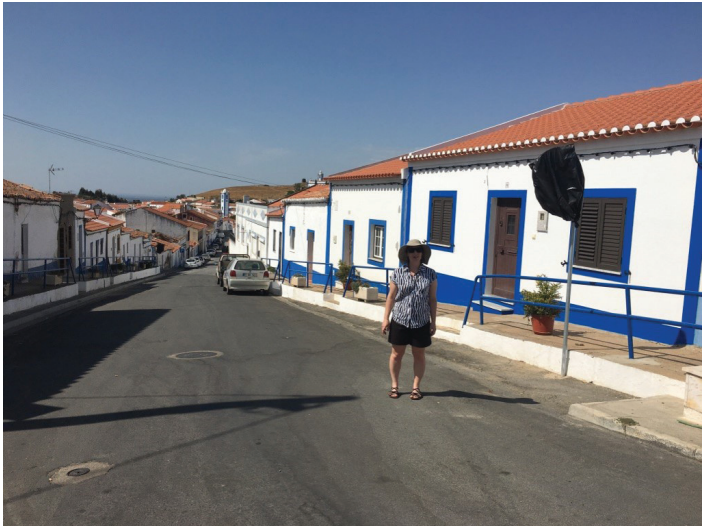

Figure 6. Hannah Joynt, Street view of Adobe Houses. Photograph: Jane Venis. where you can go to buy things. We had been there for three weeks and I remember saying to you, "Jane, you won't believe this, but I found a new shop."There are no signs anywhere. The people don't need signs because they know where everything is.

Hannah: Remember when we discovered the bullfighting ring?

Jane: This brings us to talk about the new, unexpected work that we made - short-duration, humorous video works that could only have happened in the context of that place - they were entirely site-specific. We realised we had discovered a new way of working. We came to Messejana to experiment within our collaborative music and drawing practice. However, we discovered a whole new way of working. That for me was the number one takeaway.

Hannah: It was opportunistic, but it was also because of the place. I think playing on the clunky, broken-down outdoor exercise equipment was a real trigger. That was one of a series of works we subsequently called Small Measures: Site-specific Responses to First World Guilt.

Jane: Yes, but it was the bullfighting ring that really started it. On our tour of the village, when we first saw it and looked at each other and thought, "OMG, we could make some work here."We have a history of seeing the absurd side of things. ${ }^{3}$ So, although we went to Portugal with a preconceived idea of making a particular type of work, the environment we found ourselves in led us to realising we could make anything we like.

Hannah: There is also something about the absurdity of the new, being in a place for the first time, a place that you are seeing as an alien, a place that you are not culturally familiar with or indoctrinated into, so you see it with very fresh eyes. The freshness and potency of seeing something for the first time, the power of the new, is something that fascinated the artist Pierre Bonnard. ${ }^{4}$ That is something that is important to my practice, too - seeing something, experiencing something for the first time, because you can never see it like that again - so you must make art, you must do something with that, draw it, record it, film it, as you will never see it with those fresh eyes again.

Jane: That is what was happening to us in the bullfighting ring. 
Hannah: I remember after the visit we both went back to the house and I asked, "What did you think of the bullring?" and you replied that it was really disturbing. Disturbing to be in a real, working bullfighting ring.

Jane: And then we asked ourselves when would we ever have the opportunity again to use a bullfighting ring to make some work in, and wondered if it was possible to get permission to use it ... and there was no problem at all, it was fine.

Hannah: We had no idea what we would make, but we knew that we just needed to go there and be there and the ideas would come, because we both had a strong reaction to the place. It was a site-specific response to the place.

Jane: It was, and I loved the way we responded with our bodies. I responded with my instruments, I played around. You were using your body by moving around, drawing in the dirt. To plant the olive branches, you had to draw and make marks. I made sounds, and we saw the absolute absurdity of being in this particular place as aliens. We had the opportunity to respond to the activity of bullfighting with a tiny gesture of peace, but we were also aware that we were in somebody else's cultural space.

Hannah: We were also in somebody else's back yard. The retirement home of Messejana backs onto the bullfighting ring - it looks down directly into the ring. The residents were watching us as we filmed our performances.

Jane: Ha yes! It was truly bonkers.

Hannah: The colour in the bullring added to the visual power of the site. The whitewashed stands of the circular amphitheatre, with bright red painted handrails and gates and things, the red/brown dirt and the blue sky - it was an incredible colour palate to work with.

Jane: Yes, and the signage around the ring, things like the "Director of Bullfighting" and the huge wooden gates with the big metal latches, where the bulls are kept waiting before they come into the ring. I will never forget your face when you came walking out of the bullpen where I had locked you in, your look of total horror and the tentative way that you stepped out into the bullring, taking on the character of the bull. And for me, the music I played - it just arrived - I had no idea what I would play, and then suddenly there were these pseudo-traditional, bullfighting-infused ukulele sounds.

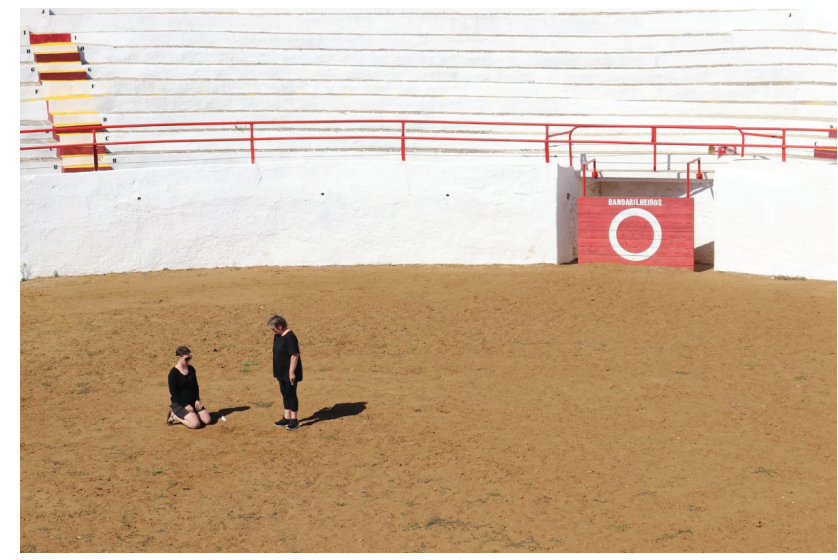

Figure 7. Jane Venis and Hannah Joynt, video Still from Flag Plant, work in progress 2019. Photograph Maria Lusquiños Torres.

Hannah: The whole thing was very much improvised, and that is a core thing - what we do is improvisation. This was an unexpected improvisation away from our studio-based drawing and music, this was a character improvisation. The way you moved, playing the ukulele, walking through the space, you took on the character of a director, you were in charge. It was so funny!

Jane: And you walked and moved in a very tentative "new bull in the arena for the first time" type of way. Monica ${ }^{5}$ told us that that's what the bulls do. They are all confused, and they don't know where they are. It was very interesting to work like that. For me, the big takeaway from our Portugal residency was how our collaborative practice has opened 


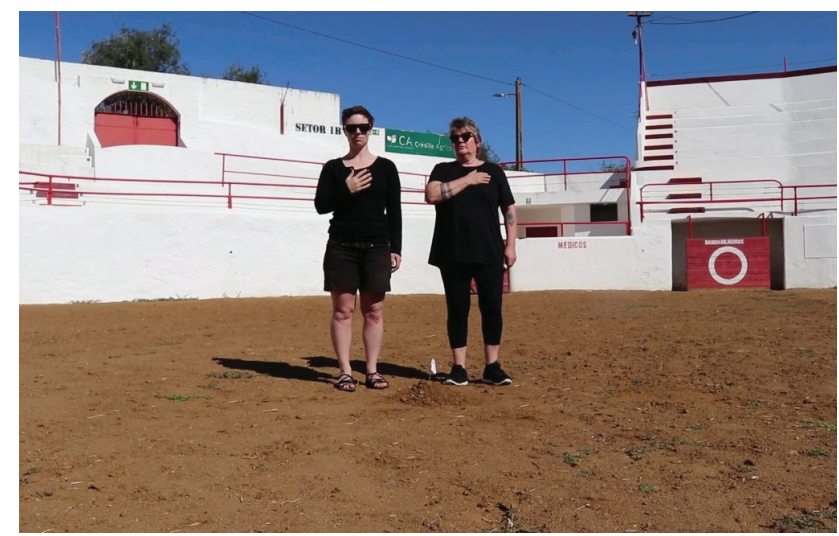

Figure 8. Jane Venis and Hannah Joynt, video Still from Flag Plant, work in progress 2019. Photograph: Maria Lusquiños Torres. up from a specific way of working in drawing and music to a performance practice which is something new and different, and I'm very excited about that. I can see that we are going to work in a myriad of different ways, and this is one of them. Who knows what the future holds?

Hannah: I think the takeaway for me is that I feel like we reached a point of resolution with our music and drawing collaboration, and then as we went to Ashburton (followed by our show this year in South Korea), we kind of signed that off. It did feel as though we had realised and resolved

that process. And I agree with you that opening up the possibilities of what our collaboration can encompass is very exciting. Also reflecting on what is it that we share from both a conceptual point of view and from an aesthetic point of view, and that is a connection with the absurd.

Jane: Not only 'the absurd' in the sense of the ridiculous, but also in a darker context relating to a feeling of futility or pointlessness - for me, the bullring works evoked both meanings as they teetered on the edge of both humour and pathos. Remember how the bone flute echoed off the walls - it was elegiac, essentially a lament. It was that very specific place that almost became a third collaborator.

Hannah: Yes, being able to engage with place, and the process of improvisation, and take risks and do things as they come up, not being too precious about choreographing performances, but letting things roll out as they may ...

Jane: And once that eye for that site-specificity was activated - it is there, and you can't 'unsee' opportunities. After we left Portugal, we were sitting in the hotel in Dubai on the way home, and we were wondering what to do as we had a 36-hour stopover, and we decided to take a desert safari tour. We saw that as an opportunity to make some work; we asked ourselves, "When are we going to be in a desert again?" We were making new work every moment. We made this ridiculous work in the desert, trudging up a boiling-hot sand dune with a teaspoon of water, and we were even making work in the airport and on the plane.

Jane: Thinking about that experience and its freedoms, who would have thought that six months later we would be in lockdown because of Covid 19? Who knows when we can do something like an international residency again? Any traveling is going to now be within New Zealand for the foreseeable future, or even in Australia as we look towards a trans-Tasman bubble.

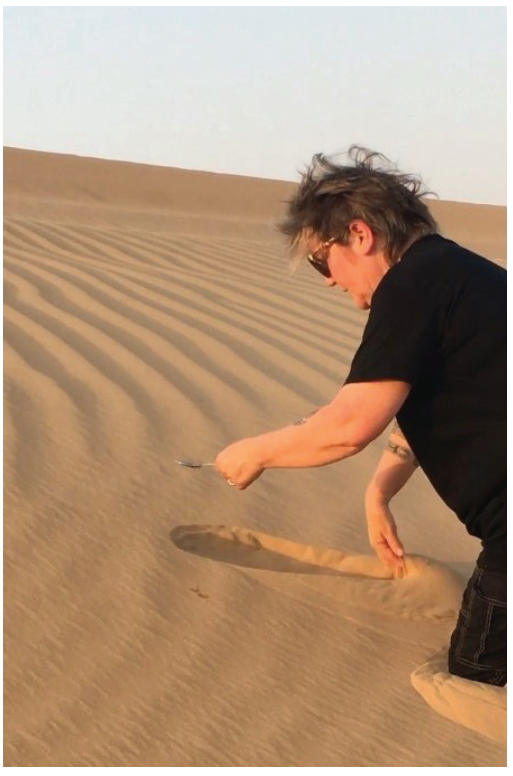

Figure 9. Jane Venis and Hannah Joynt, video Still from Spoon Dubai Desert, work in progress 2019. Photograph: Hannah Joynt. 
The physical space of where we go for the residency is of course important, but having time set aside for ideas to develop is equally essential. Carving out a space to do our work is something we did in Ashburton Art Gallery just six weeks after our return from Portugal. And we also made Small Measures works in our down time - because the Rangitata River flooded, and we couldn't get home.

Hannah: Yes, what works best for our process is if we have an intense time set aside where nothing else is going to be influencing us (such as teaching), where we have this isolated time where we live and make art in the same space. It is in those informal day-to-day situations such as cooking dinner that our ideas develop through conversations; the living collaboration is a really important creative process for us.

\section{Jane and Hannah:}

In our application to Buinho, we said:

We all have different non-verbal modes of expressing ourselves. In our performances we are initiating dialogue with each other in our own individual creative languages. How might a mark be interpreted? How might sound be interpreted? As the notion of improvisation and spontaneous expression is common to both drawing and music/sound performance, what will collaborative performances look and sound like? We are keen to see some of these ideas also played out in your community.

We performed for and with children in the local school in Messejana, and for local residents in the town square, and also really enjoyed engaging in studio critiques with the other art residents in the Buinho programme. A key work, Messejana Jantar (see Figure 4), a large three-panel drawing with three separate soundtracks, has been exhibited in both of our recent solo exhibitions: firstly, in "Drawn to Sound" in the Ashburton Gallery (December 2019 - March 2020), ${ }^{6}$ and then as part of "Dual" at the CICA Museum in Gimpo, South Korea, in April 2020. ${ }^{7}$ We are still editing the Small Measures works and looking for the right opportunity to exhibit them. 
Hannah Joynt (๑ORCID No 0000-000 I-5952-1 191) is a contemporary drawing practitioner who works in a range of media, processes and scales. Her studio practice is concerned with researching notions of "drawing as a language." Jane Venis (@ORCID No 0000-000 I-557I-6354) a musician, performance artist and maker of sculptural musical instruments. Her work is often playful and experimental, and engagement with the viewer is critical to her practice. Visual interpretation of sound and audio interpretation of mark making is a continuing exploration of "drawing as a language" and forms a key part of their collaboration.

Hannah and Jane have collaborated together over many years, including teaching drawing together at the College of Art, Design and Architecture at Otago Polytechnic in Dunedin, New Zealand.

I Buinho Residency website: https://buinho.pt/residency-2/.

2 The connection between mark making and music has a long history in modernism, as seen in the practice of Russian painter and theorist Wassily Kandinsky and his exploration of colour and sound, and in Piet Mondrian's links to jazz. Closer to home, in New Zealand in the 1980s artist Michael Smither worked in collaboration with musicians in live performances. More recently, the interest in contemporary performance drawing has been growing among groups in the UK - for example, Draw to Perform, an international performance drawing community which we see as part of our community of practice. See https:// drawtoperform.com/.

3 As in our early humorous and experimental music-making as part of The Rickety Gulumpy Bad Time Band (2006).

4 Sargy Mann, Bonnard: Drawings (London: John Murray, 1991).

5 Buinho Residency co-ordinator Monica Reiss.

6 Ashburton Art Gallery, “Drawn to Sound," https://ashburtonartgallery.org.nz/exhibition/drawn-to-sound/.

7 CICA Museum, "Jane Venis and Hannah Joynt Solo Exhibition," https://cicamuseum.com/jane-venis-and-hannah-joynt-soloexhibition/. 